\title{
BOOK REVIEWS AND NOTICES
}

\author{
IAN M. CHURCH
}

Fuller Graduate School of Psychology

\section{Alvin Plantinga and Michael Tooley, Knowledge of God, Blackwell Publishing, 2008.}

In this book, Alvin Plantinga and Michael Tooley debate the epistemic status of theistic belief. And as you might expect from philosophers of their calibre, the arguments laid out by both are robust and cogent. The book begins with opening statements from both philosophers (each being roughly 70 pages long), followed by two sets of two responses.

While those already familiar with Alvin Plantinga's other work will not be terribly surprised by the arguments he makes in his opening statement, they are, nevertheless, still extremely relevant and are presented in perhaps their clearest form. In his opening statement (and after some preliminary comments regarding theism in general), Plantinga offers a three-fold argument against philosophical naturalism (the thought being that naturalism is the only real alternative to theism, such that the defeat of naturalism would lend credence to theism). First, Plantinga argues that naturalism cannot rightly account for the notion of proper function, which in turn means that naturalism cannot account for 'malfunction or dysfunction ... health or sickness, sanity or madness'; indeed, by Plantinga's lights, in not being able to account for proper function, naturalism cannot account for knowledge (p. 1). Secondly, Plantinga argues that naturalism is self-defeating, that the naturalist is committed to the sort of deep and debilitating skepticism according to which he can't trust his cognitive faculties to furnish him with mainly true beliefs; he has a defeater for whatever he believes, including naturalism itself' (p. 1). Thirdly and finally, Plantinga argues that naturalism (insofar as it is committed to materialism regarding human beings) cannot account for belief, that materialist forms of naturalism are committed to eliminativism regarding belief, that 'if naturalism is true, no one believes anything' (p. 19). 
Michael Tooley, in his opening statement, argues that the belief in the existence of God is not epistemically justified because various 'facts about the evils found in the world' make the existence of God (very) unlikely (p. 70). To this end, Michael Tooley begins by making some preliminary comments regarding (a) the relevant concept of God under consideration, (b) that God's relation to the prevailing, historical religions of Christianity, Islam, and Judaism, (c) how identifying the relevant concept of God with the God of any those three religions affects the argument from evil, and (d) the nature of debate at hand, whether it should be framed in terms of knowledge or simply epistemic justification (Tooley opts for the latter). Once this has been done, Tooley begins to build his case for atheism. He starts by briefly surveying a number of arguments for atheism, which he groups into a priori arguments, a posteriori arguments that do not involve moral claims, and a posteriori arguments that do involve moral claims. And in so doing, Tooley argues (a) that atheism (not theism or agnosticism) is the default position in the debate, (b) that it is unlikely that there are immaterial minds, and finally (c) that the argument from evil is the 'most forceful' argument in favour of atheism (p. 71). As such, the argument from evil becomes Tooley's main focus in the latter half of his opening statement. That said, however, Tooley acquiesces that '[s] etting out the argument [from evil] properly is ... rather more difficult than has generally been appreciated'; as such, the bulk of his work at this point is devoted to surveying various formulations of the argument from evil ('abstract versus concrete formulations ... incompatibility versus evidential formulations; subjective versus objective formulations; and ... axiological versus deontological formulations') and subsequently fully elucidating and defending his favoured model (p. 71).

In Chapter 3, 'Reply to Tooley's Opening Statement', Plantinga's main target is, of course, Tooley's favoured formulation of the argument from evil. (There are, no doubt, several other important arguments that Plantinga makes in his first reply. For example, it seems to me that Plantinga does an excellent job countering Tooley's claim that atheism is the default position. That said, however, such arguments are more ancillary, and I will not consider them here.) According to Plantinga, 'Tooley's statement of the argument gives us believers in God a wonderful target; if we can show that this formulation of the argument doesn't succeed, it seems unlikely, for the moment, at any rate, that any formulation will' (p. 153). Thankfully for 'us believers' Plantinga not only argues that Tooley's probabilistic argument from evil does indeed 
fail, but he argues that even if it didn't, theism 'might still be more likely than not on our total evidence' (p. 152). After all, as Plantinga points out, ' $[\mathrm{m}]$ ost Christian thinkers have held that there are other sources of justification for belief in God; religious experience, for example, or something like [John] Calvin's Sensus divinitatis, or Thomas Aquinas's internal instigation of the Holy Spirit' and these other sources of justification might very well trump any justification to the contrary from Tooley's argument from evil (p. 153).

In Chapter 4, 'Reply to Plantinga's Opening Statement', Michael Tooley straightforwardly responds to each of Plantinga's arguments against naturalism. He begins by arguing that health, sickness, or even knowledge cannot, contra Plantinga, be appropriately analyzed in terms of proper function; if this is right, then Plantinga's claim that naturalism cannot account for such concepts because it cannot account for proper function does not get off the ground. Next, Tooley addresses Plantinga's third argument against naturalism, that naturalism (insofar as it is committed to materialism regarding human beings) cannot account for belief. Given a causal theory of propositional content, Tooley argues naturalism (of the relevant sort) can indeed account for belief. And what is more, if such a causal theory of content is indeed true, Tooley argues, it is no longer clear that naturalism is vulnerable to the aforementioned 'deep and debilitating skepticism according to which he can't trust his cognitive faculties to furnish him with mainly true beliefs', the second objection to naturalism in Plantinga's opening statement.

The book concludes with Plantinga and Tooley giving brief (roughly 15 pages), final responses to the initial responses. The main thrust of Plantinga's closing statement (entitled 'Can Robots Think?') argues that 'Tooley merely assumes that the content of belief is fixed by causal relations, and, furthermore, so fixed that most beliefs will be true' (p. 232 - emphasis Plantinga's). The main thrust of Tooley's closing statement, in contrast, focuses on (a) shoring up his arguments for atheism being the default position in the debate, (b) defending his argument from evil, (c) questioning the existence (and the epistemic value) of non-inferential justification in favour of the existence of God, and (d) noting that even if all of Plantinga's arguments against naturalism are successful that does not necessarily lead us to theism (e.g. it may lead us to some form of supernaturalism). In the end, neither Plantinga nor Tooley are compelled to yield, both feel as though their arguments remain cogent and sound. 
I highly commend Knowledge of God. While I am, no doubt, inclined to side with Plantinga in the end, both Plantinga and Tooley do an amazing job. The arguments they both lay out are philosophically rich, robust, and truly seminal. The main shortcoming of the book, as I see it, is a shortcoming of these sorts of debates in general. While the arguments levelled in this book are of a high quality and are extremely useful, the nature of the debate is such that it spans broad, established disciplines with their own worlds of literature. In debating the epistemic status of theistic belief, Plantinga and Tooley occasionally make highly contested claims about morality, theology, the nature of logic, epistemology, the philosophy of mind, etc. - for example, regarding Plantinga's second objection to naturalism in his opening statement, Tooley notes 'If [Plantinga] is right, then virtually all of philosophy of mind of the past half-century or so has been radically off-track.' - and that may be the way it has to be; however, it is, nevertheless, occasionally frustrating and dissatisfying (p. 190). Regardless, Knowledge of God is an excellent book, which I would wholeheartedly recommend to anyone with the interest and technical familiarity and certainly to any graduate students studying philosophy of religion.

\section{IAN JAMES KIDD}

\section{Durham University}

\section{Robert A. Hinde. Why Gods Persist: A Scientific Approach to Religion $2^{\text {nd }}$ ed., Routledge, 2010.}

Across its history, Christianity and other religions have demonstrated a consistent capacity to respond to ongoing criticism. Those critics, whether historical or contemporary, have used various tactics to try to undermine religion. Despite the tenacity and ingenuity of these criticisms, especially those invested in the modern sciences, a once-andfor-all challenge to religion is unforthcoming. Responding to this fact, Robert A. Hinde emphasises that 'something more than a sledgehammer, however skilfully it is wielded, is needed. We need to seek a scientific understanding of religion's extraordinary resilience' (p. viii). The aim of this book is, then, to provide that understanding of religion, thereby enabling, if only in part, the formation of a 'a happier world' (p. ix). 